Article

\title{
Resistance to Anthracnose (Colletotrichum lentis, Race 0) in Lens spp. Germplasm
}

\author{
Eleonora Barilli ${ }^{1, *,+} \mathbb{D}$, Juan Moral ${ }^{2,+}$, Thaïs Aznar-Fernández ${ }^{1}$ and Diego Rubiales ${ }^{1} \mathbb{D}$ \\ 1 Institute for Sustainable Agriculture, CSIC, Av. Menéndez Pidal s/n, 14004 Córdoba, Spain; \\ tisseta@gmail.com (T.A.-F.); diego.rubiales@ias.csic.es (D.R.) \\ 2 Department of Agronomy, University of Córdoba, Campus Rabanales, 14071 Córdoba, Spain; \\ juan.moral@uco.es \\ * Correspondence: ebarilli@ias.csic.es; Tel.: +34-957-499-211 \\ + Both authors equally contributed to this work.
}

Received: 9 October 2020; Accepted: 13 November 2020; Published: 16 November 2020

\begin{abstract}
Anthracnose, caused by the fungal pathogen Colletotrichum lentis, is a severe disease of lentil (Lens culinaris) causing premature defoliation, necrotic stem lesions that lead to plant wilting and death in susceptible varieties. Two races of $C$. lentis ( 0 and 1 ) have been described so far. Race 0 is the most virulent one and limited genetic resistance is available to date. To address this scarcity of resistance, we screened a germplasm collection covering different Lens spp. originating from different countries for $C$. lentis race 0 resistance. Leaf and stem damage and plant mortality were assessed on seedlings inoculated under controlled conditions. A significant variability was observed among accession. Most of the collection studied was highly susceptible, but some levels of resistance were identified in about $15 \%$ of the accessions. The highest levels of resistance were identified in L. ervoides accessions PI572330, PI572334 and PI572338. Moderate resistance was also identified in 10 L. culinaris ssp. culinaris accessions but not in the remaining species studied. Selected accessions showed potential to integrate several breeding programs.
\end{abstract}

Keywords: anthracnose; Colletotrichum lentis; disease screening; lentil; plant resistance

\section{Introduction}

Lentil (Lens culinaris Medik.) is an annual, herbaceous, self-pollinating cool-season pulse crop with appreciable importance as food. In 2018, lentils were cultivated worldwide in more than 6 million hectares [1]. The largest producers are Canada, India, Turkey and the USA [1]. Lentil production can be constrained by a number of pests and diseases [2]. Among these, anthracnose is a globally important fungal disease. The causing agent was named until 2014 as Colletotrichum truncatum (Schwein.) Andrus \& W.D. Moore. Then, it was renamed as C. lentis Damm based on (i) its host specialization on Lens and Vicia species [3]; (ii) the morphology of the conidium and (iii) the sequence of ITS (internal-transcribed-spacer) region of ribosomal DNA [4-6]. During the last decade, anthracnose has turned into one of the most damaging lentil diseases in countries such as Canada and USA [6-8]. Yield losses up to $70 \%$ on susceptible lines can easily occur under high disease pressure, favorable climatic conditions and absence of chemical control [9].

The species C. lentis can survive for several years on plant debris that remain in the field after harvest, such as microsclerotia and conidia [10]. The pathogen requires more than $16 \mathrm{~h}$ of leaf wetness in combination with temperatures between 20 and $30^{\circ} \mathrm{C}$ to infect the host plant [10]. Initial symptoms on leaves are small yellow spots that enlarge into brown-colored lesions with a distinct dark margin. This might result in premature leaf drop. In the stem, the first lesions appear in its base from where they progress upwards [9]. Large stem lesions can surround the whole stems and penetrate the vascular 
tissue, causing wilting with subsequent plant death. As soon as lesions become necrotic, acervuli develop, producing abundant conidia [10] and then microsclerotia [6]. In susceptible lentil lines, more than $10 \%$ of the harvested seeds could show necrotic lesions affecting their quality and market sale. During the growing season, the inoculum is primarily spread by rain splash and secondarily by windblown infected debris or during the harvesting process [7,11]. Under field conditions, C. lentis can severely affect other legume species such as faba bean (Vicia faba L.) and vetch (Vicia sativa L.) and, with minor severity, field pea (Pisum sativum L.) and chickpea (Cicer arietinum L.) [3].

The pathogen $C$. lentis is a hemibiotrophic fungus that causes intracellular colonization of plant tissues [7]. The fungus has to go through a short biotrophic phase with a length of several days depending on environmental conditions, before change to a destructive necrotrophic growth [12]. Conidia develop a germ tube that originates a melanized functional appressorial, essential to successfully penetrate the host [8]. Penetration pegs, which form on the appressoria, shortly penetrate the epidermis and subsequently, infection vesicles appear in the apoplastic space of epidermal cells below the penetration sites [6]. The primary hypha, essential for successful infection and symptom development, invaginates the plasma membrane of epidermal cells and plasmolysis starts [4]. Pathogens move from the symptomless biotrophic phase to a necrotrophic destructive phase, during which the fungus invades and kills host cells $[4,6]$. When environmental conditions are favorable to pathogen development, the latent period for $C$. lentis infection is about one week, allowing the fungus to accomplish several cycles of infection during the field growing season [10].

Based on severity of both leaf and stem lesions, two pathogenic races (named races 0 and 1 ) of C. lentis have been described. These races have different virulence on lentil differentials both under controlled and field conditions, race 0 being more aggressive than race 1 [7]. The search for sources of resistance in the cultivated lentils (L. culinaris subsp. culinaris) led to the identification of several accessions with high levels of partial resistance to race $1[7,11,13]$. This resistance to race 1 is conferred by a combination of recessive (ctr1 and $c t r 2)$ and dominant $(C t R 3, C t R 4$ and $C t R 5)$ genes $[6,14]$. On the contrary, little resistance has been identified so far in cultivated lentils to race 0 [7], and the genetics of resistance to race 0 in L. culinaris have not yet been examined [6]. However, some effective resistance to both races, and particularly the virulent race 0 , has already been identified in L. ervoides (Brign.) Grande and L. lamottei Czefr. [7,13]. Thereafter, lentil wild relatives could be valuable sources for disease resistance to anthracnose [15]. The objective of our studies was to identify additional sources of resistance to $C$. lentis race 0 in order to increase the genetic background for resistance for future breeding programs.

\section{Materials and Methods}

\subsection{Plant Material and Growing Conditions}

A collection of 250 accessions of species and subspecies of the genus Lens was screened for resistance to $C$. lentis race 0 under controlled conditions. The collection consisted of L. culinaris subsp. culinaris (204 accessions), L. culinaris subsp. orientalis Boiss. (Ponert) (10 accessions), L. culinaris subsp. odemensis (Ladiz.) M.E. (5 accessions), L. ervoides (8 accessions), L. nigricans (M. Bieb.) Godr. (21 accessions) and L. lamottei (2 accessions). Accessions originated from 37 countries were provided by CRF-INIA (BGE-code; 84 accessions) and USDA (PI- and W6- codes; 166 accessions).

Seeds were stored at $4{ }^{\circ} \mathrm{C}$ until usage. Seeds were surface sterilized by immersion in a $10 \%$ solution of commercial bleach $(\mathrm{NaClO})$ in sterile water for $2 \mathrm{~min}$ and allowed to air dry on a laboratory bench before sowing. Disinfested seeds were scarified by nicking with a razor blade and pregerminated on wet filter paper in Petri dishes for $72 \mathrm{~h}$ at $4{ }^{\circ} \mathrm{C}$ to ensure experiments with a uniform plant development stage. Petri dishes were then transferred to $20-22^{\circ} \mathrm{C}$ for $5-7$ days. Thereafter, the seeds were planted in plastic pots $\left(15 \times 15 \times 15 \mathrm{~cm}\right.$ with $250 \mathrm{~cm}^{3}$ each of $1: 1$ sand and peat mixture) under controlled conditions, $20 \pm 2{ }^{\circ} \mathrm{C}, 65 \%$ relative humidity and a photoperiod of $14 / 10 \mathrm{~h}$ day/night regime with $150 \mu \mathrm{mol} \mathrm{m}{ }^{-2} \mathrm{~s}^{-1}$ irradiance at plant canopy. The experimental design consisted of three randomized 
blocks with six seedlings per accession and block sown in two pots (three seedlings per pot). Each block consisted of a separate $80 \mathrm{~cm}$-high bench located in the controlled chamber.

Pots were placed in plastic trays with a capacity of 48 pots each. In each tray, two pots with the local susceptible "S12" accession (L. culinaris subsp. culinaris) were used as a susceptible control to verify adequate disease density during inoculation and uniformity of infection among trays. Plants were irrigated by manually filling the trays with $\pm 1 \mathrm{~cm}$ water every $48 \mathrm{~h}$.

\subsection{Fungal Isolates}

A previously well-characterized isolate of $C$. lentis race 0 (isolate A8, race 0) [16] was used for the study. Single-spore isolates were cultured in Petri dishes containing potato dextrose agar (PDA) (Sigma Aldrich, Saint-Quentin Fallavier, France) with chloramphenicol (5\% $(v / v)$ at $12 \mathrm{~mL} \mathrm{~L}^{-1}$ of medium). Petri dishes were incubated at $20 \pm 2{ }^{\circ} \mathrm{C}$ under a $12 \mathrm{~h}$ photoperiod at $150 \mu \mathrm{mol} \mathrm{m}{ }^{-2} \mathrm{~s}^{-1}$ photon flux density for $48 \mathrm{~h}$.

\subsection{Fungal Inoculation and Incubation}

Lentil seedlings were inoculated 3 weeks after sowing by spraying with a conidial suspension of $5 \times 10^{5}$ conidia $\mathrm{mL}^{-1}$ in sterile water with Tween-20 $(0.03 \%, v / v)$ at a rate of $1 \mathrm{~mL}$ per plant [10]. Thereafter, pots were placed into a dark humidity chamber with $100 \%$ relative humidity for $48 \mathrm{~h}$ incubation, at a temperature of $20 \pm 2{ }^{\circ} \mathrm{C}$. After this time, the plants were returned to growth chamber conditions as described in Section 2.1.

To test the plant infection by $C$. lentis and exclude other pathogens, random samples of 5-10 symptomatic leaves and stems were collected at $120 \mathrm{hpi}$, washed for $1 \mathrm{~min}$ in $10 \%$ bleach and dried in a flow chamber. Then, plant tissues were transferred to PDA with chloramphenicol (Figure 1) until C. lentis was reisolated. The species $C$. lentis was identified according to the type of conidia and its formation using a bright field microscope at 40× magnification (Leica Microsystems, Wetzlar, Germany).

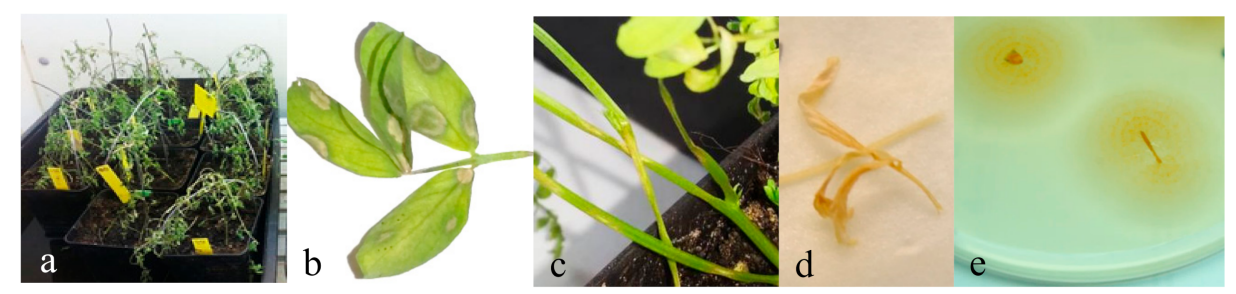

Figure 1. Damage produced by C. lentis race 0 on the susceptible check (S12) by 120 hpi: (a) whole plant's appearance; (b) damages on leaves; (c) damages on stems; (d) infested leaf dried in flow chamber; (e) PDA + CLF Petri dish with fungus developed from infected leaf segment (upper part) and stem (lower part).

\subsection{Disease Evaluation and Statistical Analysis}

Anthracnose incidence and severity of damage produced on plant leaves and stems were assessed at 120 and $192 \mathrm{~h}$ post-inoculation (hpi). Plant mortality (PM) was assessed as percentage (\%) of dead seedlings. Damages were separately assessed in leaves (leaf damage, LD) and stems (stem damage, $\mathrm{SD}$ ) with the help of a 0 (no symptoms) to 5 (deep and coalescent lesions) rating scale developed by Buchwaldt et al. [11].

Area under the disease progress curves were calculated using both LD and SD dependent variables (AULDPC and AUSDPC, respectively) by trapezoidal integration [17]. Data of AULDPC and AUSDPC were standardized considering the reaction of the susceptible control S12 and the number of days alive (sAULDPC and sAUSDPC, respectively) [18].

The mean and standard error of the mean of the dependent variables (sAULDPC, sAUSDPC and PM) were calculated by accession, subspecies, and species. The relationships between the sAULDPC, 
sAUSDPC and PM were calculated using Spearman's correlation. All the data analyses were conducted using Statistix 10 Software (Analytical Software, Tallahassee, FL, USA).

The phenotypic reaction of the Lens accessions against $C$. lentis infection was classified using the aforementioned 0-5 rating scale [11]. Thus, lentil accessions were classified as highly resistant (HR), resistant (R), moderately resistant (MR), moderately susceptible (MS), susceptible (S) and highly susceptible (HS), when their inoculated replicated plants showed an average SD of 0 (no lesions on the stem), 1 (just superficial lesions on the stem), 2 (a few deep lesions on the stem base), 3 (a mixture of superficial and deep lesions on the whole length of the stem, no die-back), 4 (deep lesions accompanied by shoot die-back or partial wilting), and 5 (deep and coalescent lesions with partial or total wilting), respectively [11].

\section{Results and Discussion}

In the present study, 250 lentil accessions were screened according to their resistance to C. lentis race 0 (COL-428). In all the performed inoculations, we used the susceptible control S12, which showed PM over 91\%, AULDC and AUSDC values of 110.6 and 129.9, respectively (Table S1). Previously, Buchwaldt et al. [11] classified lentil accessions according to the severity of symptoms on the seedling stems using the $0-5$ rating scale, since this dependent variable was well correlated with the plant mortality. Because there was a significant a positive correlation between both variables PM and sAUSDC (Spearman's correlation, $r=0.401 ; p<0.001$ ), we used the classification method proposed by the above-mentioned authors [11]. As an exception, accessions 1318 (L. ervoides) only showed superficial stem lesions but all its replicated plants died at $192 \mathrm{hpi}$. For this reason it was classified as HS. Moreover, clustering analyses were used for classification of the lentil accessions considering sAULDPC, sAUSDPC and PM as dependent variables, individually or as a whole, following Moral et al. [19], butresults were inconclusive, since there was dissimilitude among the formed groups.

Although a wide range of disease response was found, the distribution was markedly skewed toward high PM and disease severities on stem and leaf lesions (HS and S responses). Most of the accessions (about $75 \%$ of the total) displayed PM values higher than the susceptible control S12, indicating their elevated susceptibility and high virulence of the used C. lentis isolate.

Although susceptible (HS, S or MS) lentil accessions were common, some accessions showed some levels of resistance (Table S1). In fact, 11 accessions (4.4\% of the collection) showed just superficial lesions on the stems and were classified as MR, as well as three accessions (1.2\% of the collection) showed PM lower than $10 \%$ and scarce symptoms on the stems (classified as R). Accessions free (immune) of disease symptoms were not found.

Availability of resistance to $C$. lentis race 0 varied with Lens species and subspecies (Figure 2). Even when scarce, levels of resistance were identified in L. culinaris subsp. culinaris with $10(5 \%)$ accessions out of 204 that classified as MR (Figure 2). These included the accessions BGE001814, BGE001882, W627758, PI283604 and PI432005, which showed reduced lesions at the stem and foliar level at least half that of the susceptible control, and a PM $<33 \%$ (Table S1, Figure 3). Remaining L. culinaris subsp. culinaris accessions were HS, S or MS.

Resistance was more frequent in L. ervoides, with three accessions out of eight that rated as $\mathrm{R}$ (PI572330, PI572334 and PI572338) and one as MR (PI572327) (Figure 2). Resistant accessions of L. ervoides showed very limited and superficial damages at both the stem and foliar level, leading to values of plant mortality ranging between $0-9 \%$. Resistance response of accession PI572330 was in line with previous reports by Tullu et al. [15]. On the contrary, resistance was not identified in L. culinaris subsp. orientalis, L. culinaris subsp. odemensis, L. lamottei nor in L. nigricans, in which all studied accessions were rated as HS, S or MS (Table S1; Figure 2), in agreement with previous findings [13,15]. 

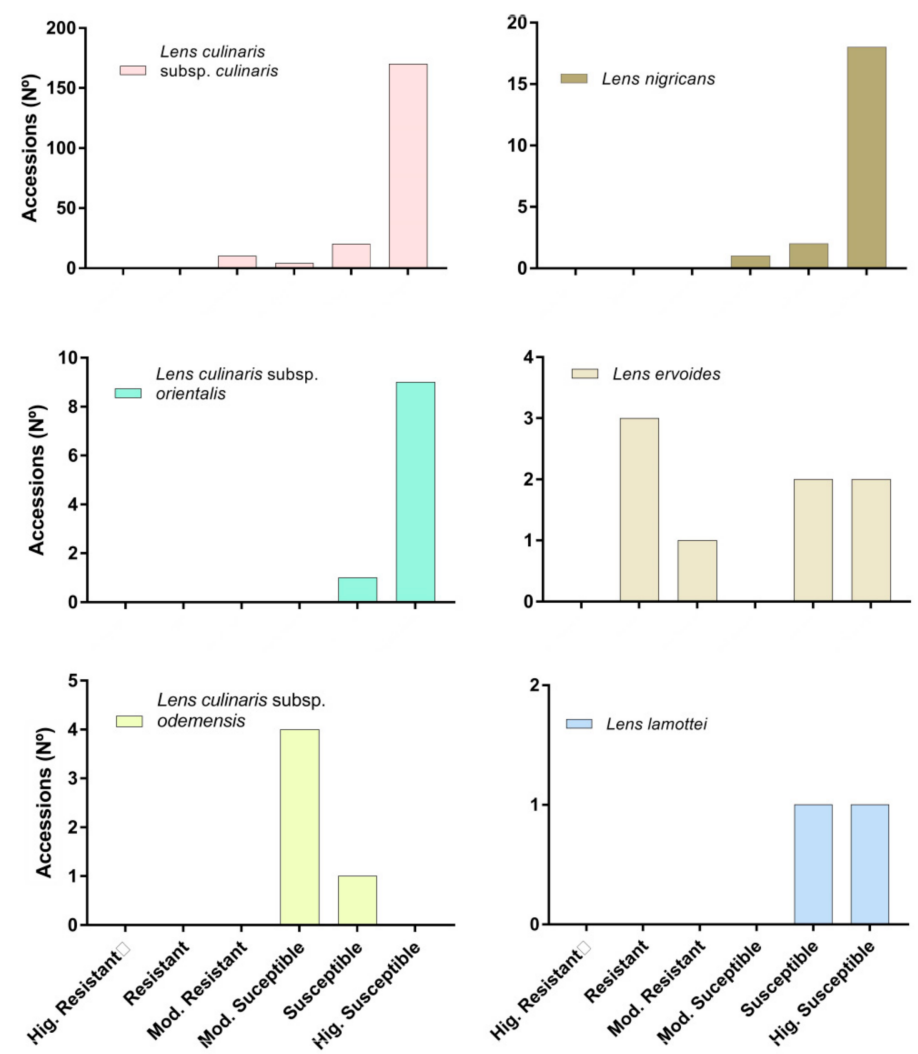

Figure 2. Plant response to C. lentis race 0 in each group of Lens spp. Macroscopical symptom appearance lead to plant classification into four groups as resistant, moderately resistant, moderately susceptible and susceptible.

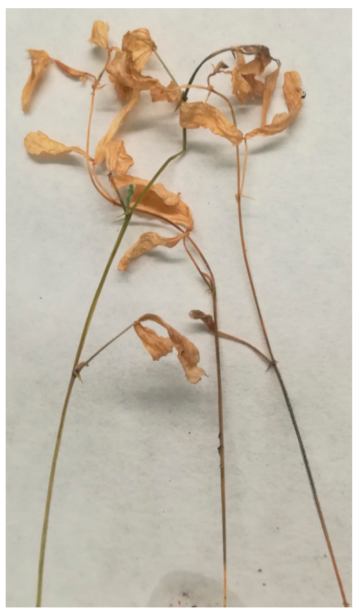

(a)

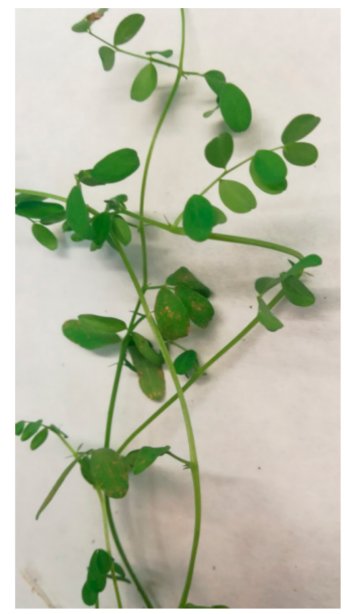

(b)

Figure 3. Symptoms in the leaves and stem of Lens culinaris spp. culinaris inoculated with C. lentis race 0 at 8 days after inoculation under controlled conditions: susceptible control S12 (a) and moderately resistant W627758 (b).

Regarding geographic origin, 12 of the moderately resistant or resistant accessions originated in the Mediterranean Basin and the Fertile Crescent (4 from Iran, 2 from Spain, 2 from Turkey, 1 from Algeria, 1 from Israel, 1 from Jordan, and 1 from Portugal), 1 was from Serbia and 1 had unknown origin (Table 1). 
Table 1. Lentil accessions screened for $C$. lentis race 0 resistance, following their geographical origin.

\begin{tabular}{|c|c|c|c|}
\hline Country of Origin & $\mathrm{N}^{\circ}$ of Accessions & Accessions Resistant (R) & $\begin{array}{c}\text { Accessions } \\
\text { Moderately Resistant (MR) }\end{array}$ \\
\hline Afghanistan & 1 & - & - \\
\hline Algeria & 2 & - & PI297287 \\
\hline Bosnia & 1 & - & - \\
\hline Brazil & 1 & - & - \\
\hline Bulgaria & 1 & - & - \\
\hline Canada & 1 & - & - \\
\hline Chile & 7 & - & - \\
\hline Czech Republic & 2 & - & - \\
\hline Egypt & 3 & - & - \\
\hline Ethiopia & 2 & - & - \\
\hline France & 4 & - & - \\
\hline Germany & 2 & - & - \\
\hline Guatemala & 1 & - & - \\
\hline India & 10 & - & - \\
\hline Iran & 43 & - & $\begin{array}{l}\text { PI431809, PI432005, } \\
\text { PI432033, PI432071 }\end{array}$ \\
\hline Israel & 4 & PI572330 & - \\
\hline Italy & 3 & - & - \\
\hline Jordan & 3 & - & PI477921 \\
\hline Lebanon & 1 & - & - \\
\hline Mexico & 4 & - & - \\
\hline Montenegro & 1 & - & - \\
\hline Morocco & 3 & - & - \\
\hline North Macedonia & 2 & - & - \\
\hline Pakistan & 4 & - & - \\
\hline Peru & 1 & - & - \\
\hline Portugal & 1 & - & PI283604 \\
\hline Republic of Cyprus & 3 & - & - \\
\hline Russia & 2 & - & - \\
\hline Serbia & 5 & - & PI572327 \\
\hline Syria & 5 & - & - \\
\hline Spain & 88 & - & BGE001814, PI298644 \\
\hline State of Palestine & 1 & - & - \\
\hline Tajikistan & 1 & - & - \\
\hline Turkey & 21 & PI572334, PI572338 & - \\
\hline Ukraine & 1 & - & - \\
\hline United States & 1 & - & - \\
\hline Unknown & 13 & - & W627756 \\
\hline
\end{tabular}

The Mediterranean Basin is considered the primary centre of diversity and domestication of Lens species $[20,21]$, and may also be the centre of diversity for resistance to diseases, as has been demonstrated for other crops.

For breeders, the identification of new sources of resistance from germplasm of different origins and their subsequent inclusion into an elite cultivated background is an essential step that needs to be efficient to develop varieties with the desired characteristics of interest. Accordingly, identification of novel sources of resistance to $C$. lentis race 0 is of great importance since resistance found until now within the Lens culinaris subsp. culinaris gene pool is very limited [22,23], with fewer than 10 accessions with slight resistance $[9,24]$ which mainly originate from Eastern Europe. Here, we identified for the first time 10 accessions of L. culinaris subsp. culinaris with MR to C. lentis race 0 . These accessions, which had both reduced plant mortality and low symptom development on leaves and stems by the pathogen have diverse geographical origin, enlarging the set of possible donors of Colletotrichum resistance available for lentil breeders. 
Three accessions from wild L. ervoides from Israel and Turkey with a highly resistant response to $C$. lentis race 0 were also described here. According to previous studies, this wild species has the highest frequency of resistant accessions for both races of $C$. lentis $[11,15,24]$. Although with some difficulties, interspecific hybridization with L. ervoides is possible. In fact, resistant progenies have already been generated by crossing a resistant wild accession of L. ervoides with a susceptible L. culinaris one, followed by embryo rescue [24-26].

Resistant accessions found here from both L. culinaris subsp. culinaris and L. ervoides are new sources of resistance to $C$. lentis race 0 , which are currently included in local breeding programs with the aim to originate material well adapted to Mediterranean rain-fed conditions. Research is now in progress to determine the number, allelism and dominance of these resistance genes.

Supplementary Materials: The following are available online at http://www.mdpi.com/2073-4395/10/11/1799/s1, Table S1: Lentil accessions screened for C. lentis race 0 resistance, following their species and subspecies classification, as well as their geographical origin. Plant mortality (\%), area under the disease progress curves with leaf disease and stem disease values (AUSLPC and AUSDPC), standard errors (SE) and classification for C. lentis response.

Author Contributions: Conceptualization, D.R.; methodology, D.R., J.M., T.A.-F., formal analysis, E.B., J.M.; genetic resources, D.R.; data curation, E.B., J.M., T.A.-F.; supervision, D.R.; writing-original draft preparation, E.B., J.M., D.R.; writing-review and editing, E.B., J.M., D.R.; funding acquisition, D.R. All authors have read and agreed to the published version of the manuscript.

Funding: The authors are greatly indebted to the Spanish Project AGL2017-82907R, which has funded this research.

Conflicts of Interest: The authors declare no conflict of interests.

\section{References}

1. FAOSTAT-Food and Agriculture Organization. Available online: http://www.fao.org/faostat/en/\#home (accessed on 20 September 2020).

2. Chen, W.; Sharma, H.C.; Muehlbauer, F.J. Compendium of Chickpea and Lentil Diseases and Pests; APS Press: St. Paul, MN, USA, 2011; pp. 6-98. [CrossRef]

3. Gossen, B.D.; Anderson, K.L.; Buchwaldt, L. Host specificity to Colletotrichum truncatum from lentil. J. Plant Pathol. 2009, 31, 65-73. [CrossRef]

4. Bhadauria, V.; Banniza, S.; Vandenberg, A.; Selvaraj, G.; Wei, Y. Cataloging proteins putatively secreted during the biotrophy-necrotrophy transition of the anthracnose pathogen Colletotrichum truncatum. Plant Signal. Behav. 2011, 6, 1457-1459. [CrossRef]

5. Damm, U.; O'Connell, R.J.; Groenewald, J.Z.; Crous, P.W. The Colletotrichum destructivum species complex-Hemibiotrophic pathogens of forage and field crops. Stud. Mycol. 2014, 79, 49-84. [CrossRef] [PubMed]

6. Buchwaldt, L.; Dzanovic, E.; Durkin, J. Lentil anthracnose: Epidemiology, fungicide decision support system, resistance and pathogen races. Can. J. Plant Pathol. 2018, 40, 189-198. [CrossRef]

7. Banniza, S.; Warale, R.; Menat, J.; Cohen-Skali, A.; Armstrong-Cho, C.; Bhadauria, V. The long path to understanding the host-pathogen interactions of Colletotrichum lentis on lentil. Can. J. Plant Pathol. 2018, 40, 199-209. [CrossRef]

8. Chongo, G.; Gossen, B.D.; Bernier, C.C. Infection by Colletotrichum truncatum in resistant and susceptible lentil genotypes. Can. J. Plant Pathol. 2002, 24, 81-85. [CrossRef]

9. Shaikh, R.; Diederichsen, A.; Harrington, M.; Adam, J.; Conner, R.L.; Buchwaldt, L. New sources of resistance to Colletotrichum truncatum race $\mathrm{Ct} 0$ in Lens culinaris Medikus subsp. culinaris obtained by single plant selection in germplasm accessions. Genet. Resour. Crop Evol. 2013, 60, 193-201. [CrossRef]

10. Chongo, G.; Bernier, C.C. Effects of host, inoculum concentration, wetness duration, growth stage and temperature on anthracnose of lentil. Plant Dis. 2000, 84, 544-548. [CrossRef]

11. Buchwaldt, L.; Anderson, K.L.; Morrall, R.A.A.; Gossen, B.D.; Bernier, C.C. Identification of lentil germ plasm resistant to Colletotrichum truncatum and characterization of two pathogen races. Phytopathology 2004, 94, 236-243. [CrossRef]

12. Armstrong-Cho, C.; Wang, J.; Wei, Y.; Banniza, S. The infection process of two pathogenic races of Colletotrichum truncatum on lentil. Can. J. Plant Pathol. 2012, 34, 58-67. [CrossRef] 
13. Vail, S.; Strelioff, J.V.; Tullu, A.; Vandenberg, A. Field evaluation of resistance to Colletotrichum truncatum in Lens culinaris, Lens ervoides and Lens ervoides $\times$ Lens culinaris derivatives. Field Crops Res. 2012, 126, 145-151. [CrossRef]

14. Buchwaldt, L.; Shaikh, R.; Adam, J.; Tullu, A.; Slinkard, A.E. Recessive and dominant genes confer resistance to Colletotrichum truncatum in cultivated lentil. Can. J. Plant Pathol. 2013, 35, 222-231. [CrossRef]

15. Tullu, A.; Buchwaldt, L.; Lulsdorf, M.; Banniza, S.; Barlow, B.; Slinkard, A.E.; Sarker, A.; Tar'an, B.; Warkentin, T.; Vandenberg, A. Sources of resistance to anthracnose (Colletotrichum truncatum) in wild lens species. Genet. Resour. Crop Evol. 2006, 53, 111-119. [CrossRef]

16. Ford, R.; Banniza, S.; Photita, W.; Taylor, P.W.J. Morphological and molecular discrimination of Colletotrichum truncatum causing anthracnose on lentil in Canada. Australas. Plant Pathol. 2004, 33, 559-569. [CrossRef]

17. Jeger, M.J.; Viljanen-Rollinson, S.L. The use of the area under the disease-progress curve (AUDPC) to assess quantitative disease resistance in crop cultivars. Theor. Appl. Genet. 2001, 102, 32-40. [CrossRef]

18. Madden, L.V.; Hughes, G.; van den Bosch, F. The Study of Plant Disease Epidemics; APS Press: St. Paul, MN, USA, 2007; pp. 11-31. [CrossRef]

19. Moral, J.; Xaviér, C.J.; Viruega, J.R.; Roca, L.F.; Caballero, J.; Trapero, A. Variability in susceptibility to anthracnose in the world collection of olive cultivars of Cordoba (Spain). Front. Plant Sci. 2017, 8, 1892. [CrossRef] [PubMed]

20. Barulina, H. Lentils of the USSR and other countries. Bull. Appl. Genet. Plant Breed. 1930, 40, 1-319.

21. Coyne, C.; McGee, R. Lentil. Genetic and Genomic Resources of Grain Legume Improvement; Elsevier: Amsterdam, The Netherlands, 2013; pp. 157-180. [CrossRef]

22. Buchwaldt, L.; Diederichsen, A. New disease resistant lentil germplasm identified at Plant Gene Resources of Canada (PGRC). In Proceedings of the 5th Canadian Pulse Research Workshop, London, ON, Canada, 28-30 November 2004; p. 204.

23. Vail, S.; Vandenberg, A. Evaluation of a clonal propagation protocol to obtain replicated disease data on infection by Colletotrichum truncatum in Lens culinaris. Crop Sci. 2010, 50, 926-932. [CrossRef]

24. Gela, T.S.; Banniza, S.; Vandenberg, A. Lack of effective resistance to the virulent race of Colletotrichum lentis in Lens culinaris Medikus subsp. culinaris. Plant Gen. Res. 2020, 18, 81-87. [CrossRef]

25. Fiala, J.V.; Tullu, A.; Banniza, S.; Séguin-Swartz, G.; Vandenberg, A. Interspecies transfer of resistance to anthracnose in lentil (Lens culinaris Medic.). Crop Sci. 2009, 49, 825-830. [CrossRef]

26. Tullu, A.; Bett, K.E.; Banniza, S.; Vail, S.; Vandenberg, A. Widening the genetic base of cultivated lentil through hybridization of Lens culinaris 'Eston' and L. ervoides accession IG 72815. Can. J. Plant Sci. 2013, 93, 1037-1047. [CrossRef]

Publisher's Note: MDPI stays neutral with regard to jurisdictional claims in published maps and institutional affiliations.

(C) 2020 by the authors. Licensee MDPI, Basel, Switzerland. This article is an open access article distributed under the terms and conditions of the Creative Commons Attribution (CC BY) license (http://creativecommons.org/licenses/by/4.0/). 